\title{
The Greenland ice sheet - a model for its culmination and decay during and after the last glacial maximum
}

\author{
SVEND FUNDER \& LOUISE HANSEN
}

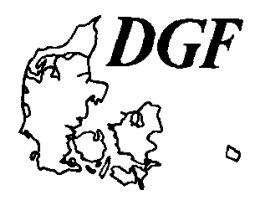

Funder, S. \& Hansen, L.: The Greenland ice sheet - a model for its culmination and decay during and after the last glacial maximum. Bulletin of the Geological Society of Denmark, Vol. 42, pp. 137-152. Copenhagen, 1996-02-01.

https://doi.org/1-0.3757-0/bgsd-1995-42-12

\begin{abstract}
Ice margin reconstructions of the Greenland ice sheet during LGM (c. 21-16 ka) and 10 $\mathrm{ka}$ are based on published onshore field evidence supplemented with recent studies on the East Greenland shelf and results of current field work in the Scoresby Sund area. Additional evidence comes from the pattern of Holocene uplift and the frequency distribution of more than $1000{ }^{14} \mathrm{C}$-dates.

During LGM, only southern Greenland (south of lat. $69^{\circ}-72^{\circ} \mathrm{N}$ ) saw a major expansion of the ice sheet with thick cover over the present coastline and onto the shelf. In the north, outlet glaciers filled fjord basins, including the Nares Strait between Canada and Green-land, and piedmont glaciers descended from coastal mountains onto the coastline, but the glaciers did not cover the shelf. Break up probably began after c. $15 \mathrm{ka}$, and took place in two discrete steps. First, the shelf and major inlets were cleared of marine based ice. There was little thinning of the ice on land, and in the northern parts there was little change at all. The driving factor during this step was calving caused by rising sea level. This lasted until c. $10 \mathrm{ka}$, but may have been consumated before the Younger Dryas. The second step began with a glacier-readvance between 10 and $9.5 \mathrm{ka}$, and after this the fjord glaciers began to retreat rapidly. Within a few millenia all the presently ice free land was exposed. The fre-quency distribution of ${ }^{14} \mathrm{C}$-dates show that the nearshore marine and terrestrial biotopes emerged in this period. The discharge of ice was both by calving and melting, and the driving force was probably increased insolation.

Maximum Holocene uplift was attained in areas of the $10 \mathrm{ka}$ ice margin, indicating that the uplift is essentially a response to the melting and unloading of ice that began at this time. In suppport of this, recent results in West, North and East Greenland indicate that the age of the marine limits decline towards the outer coasts, away from the $10 \mathrm{ka}$ ice margin.
\end{abstract}

Svend Funder and Louise Hansen, Geological Museum, University of Copenhagen, Østervoldgade 5-7, DK-1350 Copenhagen K, Denmark, 17th November 1995.

\section{Introduction}

The last glacial maximum (LGM) was the time when the large ice sheets reached their culmination during the last ice age, as signified by the global sea level minimum at c. $18{ }^{14} \mathrm{C}$-ka (Bard, Fairbanks \& Hamelin 1992; $\mathrm{ka}=$ kiloannua $=1000{ }^{14} \mathrm{C}$-years before present). The culmination was followed by rapid ice sheet disintegration, and in the course of 10 millenia both the North American and Eurasian ice sheets had vanished. In the northern hemisphere only the much smaller Greenland ice sheet remained (e.g. Peltier 1994). This paper gives an outline of the Greenland ice sheet's behaviour during this turbulent period, and its response to global change. Reconstructions are presented for the ice sheet distribution at LGM and $10 \mathrm{ka}$. They are compiled mainly from onshore field observations from all parts of Greenland, but supplemented with recently published results from marine geological work on the East Greenland shelf (Fig. 1), as well as from current field work in the Scoresby Sund area. Additional evidence comes from an analysis of the general pattern of postglacial isostatic uplift, and from the age frequency distribution of more than $1000{ }^{14} \mathrm{C}$-dates from all parts of the country. The reconstructions are an updated version of those presented by Funder (1989) which gives references to the older literature. Figure 1 shows localities mentioned in the text, and distribution of shelf banks and transverse troughs which have played a major role as obstacles or drainage channels for the ice sheet. 


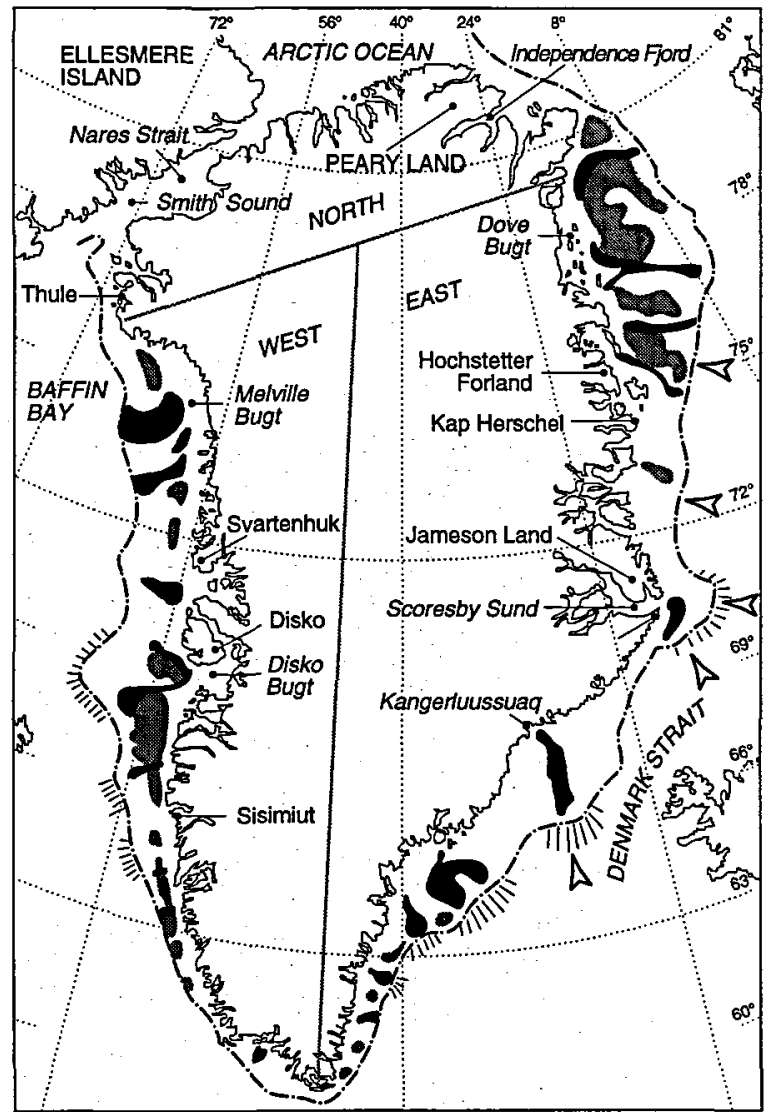

Fig. 1. Greenland with place names mentioned in the text and morphological features on the shelf. Hachured line: shelf edge (500 m contour) with prominent trough mouth fans (slope signature). Black: transverse channels. Grey: shallow banks. White arrows: location of seismic traverses with coring. Shelf morphology from Funder \& Larsen (1989).

\section{Ice distributions}

The limits for LGM ice coverage shown on Fig. 2 are based on heterogenous evidence, mainly from land. A major problem lies in assessing the distribution of thin grounded ice on the shelves. This has usually been done by extrapolation from ice thicknesses, based on the altitudes of weathering limits on coastal mountains. We have chosen to accept these argumentated views, even though the recent studies on the shelf indicate that maybe they should rather be regarded as minimum estimates.

The " $10 \mathrm{ka}$ " (i.e. 10-9.5 ka) ice margin is based on more solid and better dated evidence such as moraines, kame terraces and outwash, which are ${ }^{14} \mathrm{C}$-dated by organic remains interpreted to be contemporaneous with or slightly younger than the glacier-movements.

A brief survey of the evidence for the ice margin reconstruction in each area is given below.

\section{West Greenland}

LGM in West Greenland was termed the Sisimiut stade by Kelly (1985), and bounded by a weathering limit where high-lying areas with autochtonous felsenmeer, tors, and surface weathering of clasts meet lower areas where these features are lacking and glacial deposits and striated surfaces are more abundant. Locally, on coastal mountains, the weathering limit is found at altitudes between 300 and $1100 \mathrm{~m}$, apparently rising from north to south (Fig. 2). This implies that LGM ice cover was thin and extended only a short distance from the present coast. Kelly (1985) therefore made a tentative correlation between these features and moraines on the inner shelf, where they mark the outer boundary of a zone of abraded bedrock, and follow along the sides of the transverse valleys that cross the shelf banks towards the open sea. The moraines occur south of lat. $69^{\circ} \mathrm{N}$, between 10 and $50 \mathrm{~km}$ from the coast (Brett \& Zarudski 1979, Roksandic 1979). On Disko, recent evidence support this picture. Here LGM was characterised by glaciers which filled the fjords and embayments and formed piedmont glaciers on the shelf blocking major valleys which were ice free at the time (Ingólfsson, Frich, Funder \& Humlum 1990; Bennike, Hansen, Knudsen, Penney \& Rasmussen 1994).

From northern West Greenland, north of $72^{\circ} \mathrm{N}$, there are few observations on ice coverage during LGM. Kelly (1985) suggested thinner ice cover and ice free areas in the Svartenhuk area because Pre-Holocene sediments without till cover and traces of glacier overriding are more widespread. Further north, in Melville Bugt, the sparse field evidence does not allow reconstruction of former ice margins.

There is no firm evidence to put a date on the Sisimiut stade in West Greenland, and the age must be inferred by extrapolation from younger events in areas

Fig. 2. Model of LGM (green) and $10 \mathrm{ka}$ (red) ice margins in Greenland. Brown areas are major ice free areas and numbers are altitudes of ice surface during LGM. Numbers in italic are minimum ${ }^{14} \mathrm{C}$-ages of initial break up of the ice margin. For references see text.

Fig. 3. Altitude of postglacial marine limits in Greenland. Revised from Funder 1989. Sources, clockwise from western North Greenland: Funder 1990a, THULE-89 Project, unpublished, Nichols 1969, Blake et al. 1992, Kelly \& Bennike 1992, Landvik and Weidick in Olesen et al. 1995, Funder \& Hjort 1980, Funder \& Abrahamsen 1988, Hjort 1981b, in press. East Greenland: Landvik 1994, Hjort 1979, 1981c, Funder 1978, 1990b, Brooks 1979, Bøgvad 1940. West Greenland: compilation by Kelly 1985, Ingólfsson et al. 1990, Bennike et al. 1994, Fredskild 1985. 


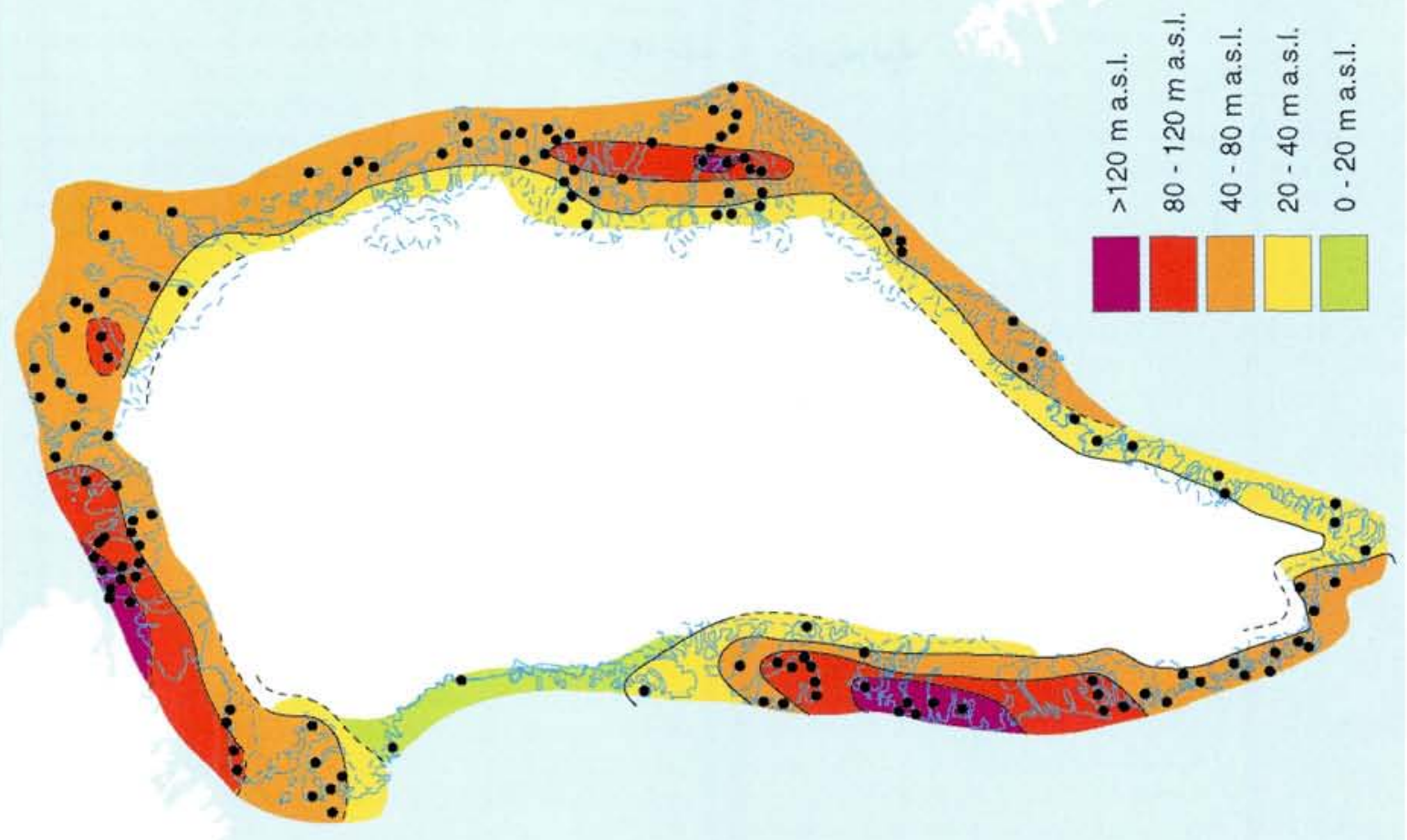

?

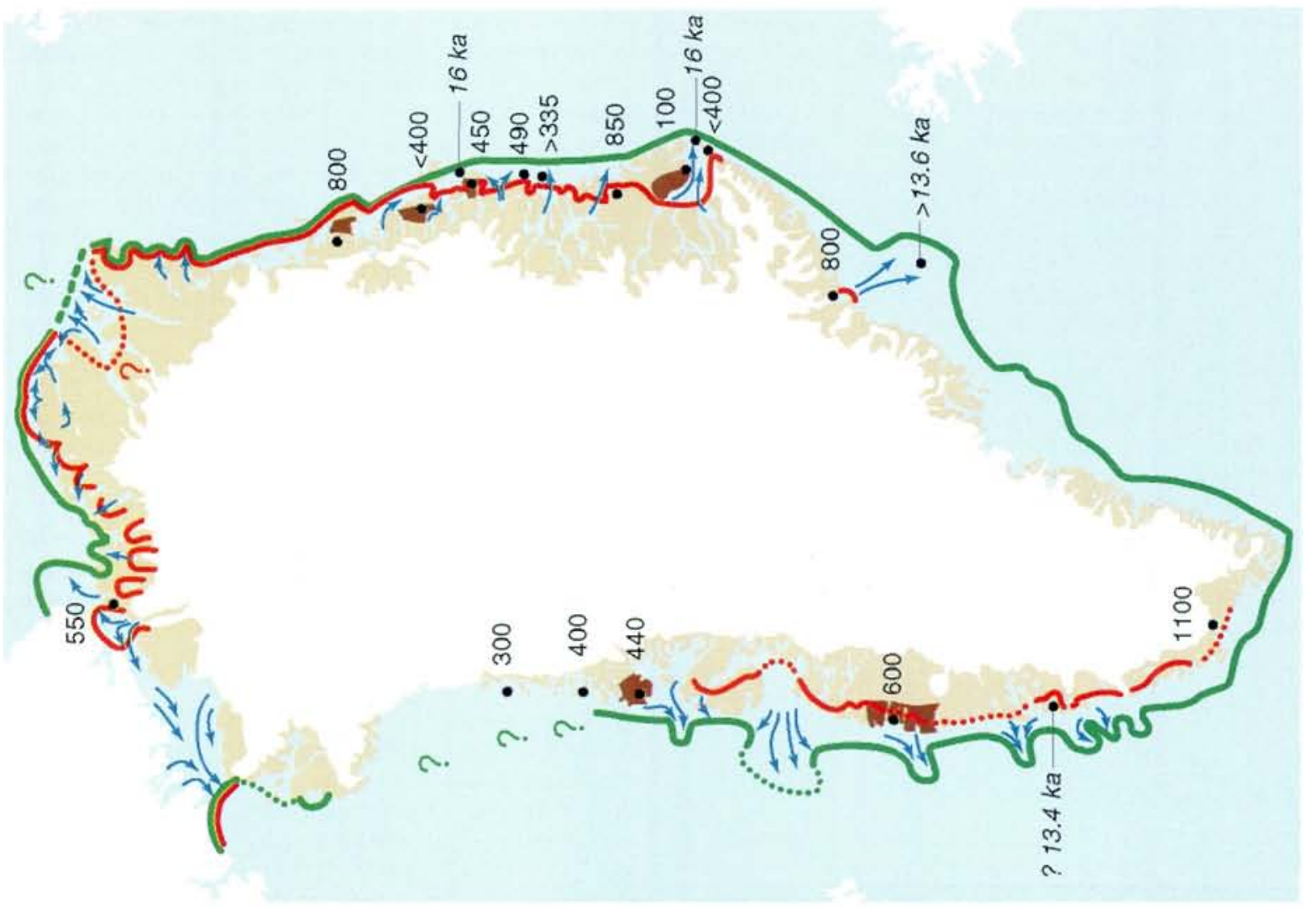

i 
that were ice covered during this stade. Kelly (1985) showed that ${ }^{14} \mathrm{C}$-dates between 10.2 and $9 \mathrm{ka}$ are rather frequent in the coastal land areas. Deglaciation on the shelf and coastal rim must therefore be older. A single ${ }^{14} \mathrm{C}$-date of $13.4 \mathrm{ka}$ obtained by Weidick (1975) on shells in southern West Greenland would further extend this, although ages in this interval should be regarded with suspicion (see discussion below). Kelly (1985) therefore estimated the ending of the Sisimiut stade to be older than 11 and possibly also older than $13.5 \mathrm{ka}$. In agreement with this, Bennike et al. (1994) showed that the coastal area at Disko was ice free before $10.4 \mathrm{ka}$, and lake basins at the outer coast south of Disko Bugt may have been ice free as early as $11.3 \mathrm{ka}$ if the ${ }^{14} \mathrm{C}$-age on minerogenic lake sediments is correct (Fredskild 1992). These estimates are all minimum ages for the disintegration of the ice after the Sisimiut Stade, and there is no evidence to estimate its duration.

The $10 \mathrm{ka}$ ice margin shown on Fig. 2 is constructed by intrapolation between moraine segments in the fjords and sometimes on interfluves. The moraines are dated by their intersection with marine deposits along a 1000 $\mathrm{km}$ stretch of the coast. This is revised from Funder (1989) with new evidence from Weidick (1993) and Bennike et al. (1994). The line contains an element of speculation, but does give the approximate location of the Inland Ice margin at this time. However, it does not represent a single climatic or glaciodynamic event. Thus, in the Sisimiut area it is represented by the moraines of the Taserqat stage, which were interpreted to have formed during a climatically conditioned readvance at $9.5 \mathrm{ka}$ (Ten Brink \& Weidick 1974, Weidick 1976). In southern Greenland, on the other hand, ice-recession apparently proceeded without noticeable halts between 14 and $8.5 \mathrm{ka}$ (Weidick 1975). The single largest outlet in West Greenland is in Disko Bugt. This large embayment was ice free in good time before a readvance of local glaciers, the Disko stade, at $9.3 \mathrm{ka}$ (Ingólfsson et al. 1990), and as discussed below, probably also at $10 \mathrm{ka}$. No major readvance of the Inland Ice margin has been recorded from this area.

In summary, the LGM West Greenland ice margin south of lat. $72^{\circ} \mathrm{N}$ was lobate and followed the inner shelf but with outlets through transverse channels. The ice sheet over the coast and shelf was thin, especially in the north, and high coastal mountains were free of ice. The ice on the shelf and possibly also in the large embayment of Disko Bugt was cleared away before c. $10 \mathrm{ka}$. After this the land based ice began to melt, especially in the central areas.

\section{North Greenland}

Fresh glacial landforms and striations in combination with considerable Holocene isostatic rebound show that a major glacier occupied Nares Strait between Green- land and Ellesmere Island during LGM (Blake 1992). It derived from the coalesced Innuitian Ice Sheet over Arctic Canada and the Greenland Ice Sheet and reached up to $550 \mathrm{~m}$ on the adjacent mountain sides on the Greenland side during the Kap Fulford Stade (Kelly \& Bennike 1992). The ice stream drained southwards towards Baffin Bay as the $50 \mathrm{~km}$ wide and $1500 \mathrm{~m}$ thick "Smith Sound Ice Stream" (Blake 1992). However, in the Thule area to the south of Nares Strait, the coastal areas are characterised by lack of fresh glacial landforms, high degree of weathering and moderate Holocene emergence, reaching a maximum of $55 \mathrm{~m}$ on Carey Øer. Apparently the ice stream never reached these areas, and LGM here was marked only by the advance of fjord glaciers within the fjords (Kelly \& Landvik 1990, THULE-89 Project, unpublished). At the other end of Nares Strait, at the Arctic Ocean coast LGM was also restricted to fjord glaciers advancing towards the fjord mouths (Kelly \& Bennike 1992). The Smith Sound Ice Stream apparently drained a large sector of the northern part of the Inland Ice, and apparently the main drainage was to the south where the ice stream must have had a calving front close to the deep waters of northern Baffin Bay. The much smaller drainage to the north indicates that melting and calving here were low because of the cold and dry climate, similar to present conditions in these areas.

Along the $500 \mathrm{~km}$ stretch of Arctic Ocean coast to the northeast of the Nares Strait region no field work has been done since the survey by Funder \& Hjort (1980). From the distribution of erratics and glacial landforms Funder \& Larsen (1982) and Dawes (1986) suggested that a large ice shelf occupied the adjacent part of the Arctic Ocean between Greenland and Canada during LGM. However, the very restricted extent of glaciers documented by Kelly \& Bennike (1992) in the source areas for the putative ice shelf makes this concept less likely, and until new field work has been conducted we suggest that the glacial land-forms along the coast were formed by piedmont glaciers descending from a local ice cap over Peary Land - and leave the problem of the erratics to the future.

Restricted fjord glaciation has recently been invoked by Håkansson, Birkelund, Heinberg, Hjort, Mölgaard \& Pedersen (1993) and Hjort (in press) also for LGM in the south-eastern part of North Greenland. Here fjords were filled by glaciers which had their fronts on the inner shelf while piedmont glaciers from the coastal mountains covered the present coastline between the fjords. Some local ice caps in the coastal area may even have been smaller than they are now (Håkansson et al. 1993).

The age of LGM in this extensive region is deduced mainly from the ages of marine faunas that invaded the areas during successive stages of the glacier recession. In the Thule region the fjord glacier had retreated to its present location before $9 \mathrm{ka}$ (Funder 1990a). At the same time the Smith Sound Ice Stream had abandoned the Canadian side of southern Smith Sound (Blake 1992), 


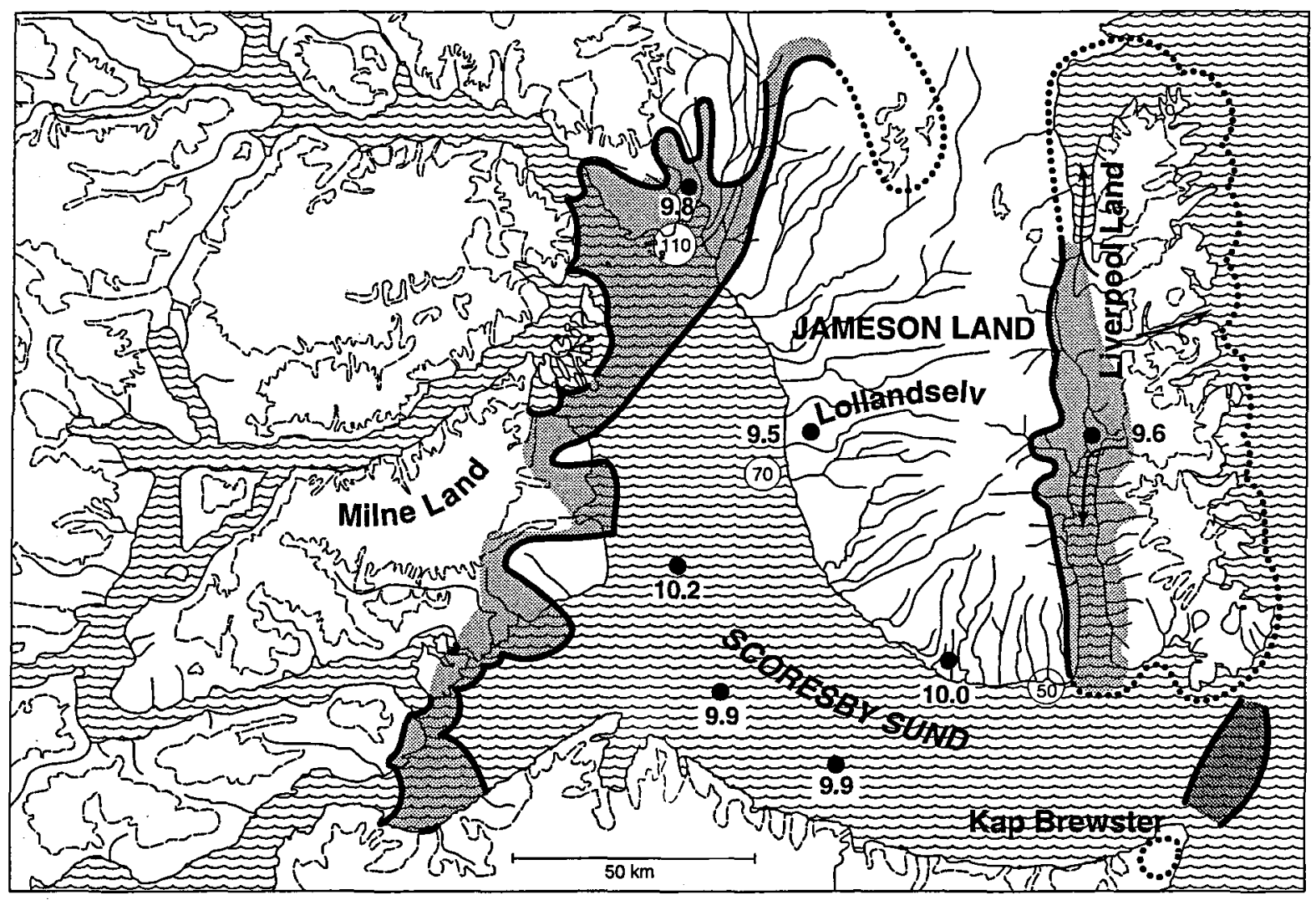

Fig. 4. Scoresby Sund area with features relevant to ice break up after LGM. Dark grey: Kap Brewster sedimentary ridge (LGM); Light grey: zone of Milne land stade moraines $(10-9.5 \mathrm{ka}) .{ }^{14} \mathrm{C}$-dates related to deglaciation (listed in Table 1). Circled numbers are altitudes of marine limits ( $m$ a.s.1.).

while it may have lingered on for some millenia along the Greenland coast (Blake, Boucherle, Fredskild, Janssens \& Smol 1992). In northern Nares Strait deglaciation had cleared the coasts and outer fjords by $10.5 \mathrm{ka}$, but the younger Warming Land stade moraines indicate readvance or long lasting stillstand in the fjords shortly before $9.5 \mathrm{ka}$ (Kelly \& Bennike 1992). At the north coast of Peary Land, Holocene faunas have been dated to $8.5 \mathrm{ka}$ (Funder \& Hjort 1980), while a sample from interior Independence Fjord indicates that this large fjord basin had been cleared of glaciers by $9 \mathrm{ka}$ (Bennike 1987). In the southeastern part of the region glacier retreat had begun before $9.1 \mathrm{ka}$ (Hjort, in press).

In summary, the North Greenland shelves saw only restricted glaciation during the LGM. The ice margins were located at fjord mouths and on the inner shelf where calving was restricted by low temperatures and permanent sea ice. An exception to this is the Nares Strait between Canada and Greenland which was occupied by the Smith Sound ice stream which calved into Baffin Bay. At $10 \mathrm{ka}$ a readvance or prolonged stillstand in the west heralded the final melting and uncovering of the land areas and in the east the Independence Fjord was ice free before $9 \mathrm{ka}$.

\section{East Greenland}

In northernmost East Greenland, recent studies indicate a slightly smaller LGM than anticipated in the previous reconstruction by Funder (1989). The outlet glaciers were thin and hardly protruded onto the shelf, and coastal uplands were free of ice (Landvik 1994; Björck, Wohlfahrt, Bennike, Hjort \& Persson 1994a; HoumarkNielsen, Hansen, Jørgensen \& Kronborg 1994), although an ice shelf existed in Dove Bugt, pinned on inner shelf islands (Hjort \& Björck 1984, Landvik 1994). Remnants of LGM ice are probably preserved in an ice cored moraine at Kap Herschel (HoumarkNielsen et al. 1994).

Dates on the marine faunas which followed the receding glaciers show that the coastal areas in northern East Greenland were cleared of ice between 10 and 9 
Tabel $1 .{ }^{14} \mathrm{C}$-dates from Scoreby Sund, used in text.

\begin{tabular}{|c|c|c|c|c|c|c|}
\hline Lab. No. & Dated material & Lat./Longt. & ConvBP & RcorrBP ${ }^{1}$ ) & & Source \\
\hline AAR-199 & $\begin{array}{l}\text { Foraminifera in marine } \\
\text { core }\end{array}$ & $\begin{array}{l}70^{\circ} 20^{\prime} 25 \mathrm{~N} \\
23^{\circ} 42^{\prime} 51 \mathrm{~W}\end{array}$ & $10340 \pm 150$ & 9890 & $\begin{array}{l}\text { Scoresby Sund. From homogenous } \\
\text { sandy mud w. dropstones, }>1 \mathrm{~m} \text { above } \\
\text { base of unit }\end{array}$ & Marienfeld 1991 \\
\hline AAR-200 & $\begin{array}{l}\text { Foraminifera in marine } \\
\text { core }\end{array}$ & $\begin{array}{l}70^{\circ} 28^{\prime} 95 \mathrm{~N} \\
24^{\circ} 40^{\prime} 47 \mathrm{~W}\end{array}$ & $10480 \pm 190$ & 9930 & $\begin{array}{l}\text { Scoresby Sund. Same as above, } 10 \mathrm{~cm} \\
\text { o. boundary to laminated mud w. few } \\
\text { dropstones }\end{array}$ & Marienfeld 1991 \\
\hline AAR-202 & $\begin{array}{l}\text { Foraminifera in marine } \\
\text { core }\end{array}$ & $\begin{array}{l}70^{\circ} 42^{\prime} 49 \mathrm{~N} \\
24^{\circ} 59^{\prime} 97 \mathrm{~W}\end{array}$ & $10760 \pm 180$ & 10210 & $\begin{array}{l}\text { Scoresby Sund. Same as above, just o. } \\
\text { boundary to laminated mud w. few } \\
\text { dropstones }\end{array}$ & Marienfeld 1991 \\
\hline $\begin{array}{l}\text { AAR- } \\
1829^{3)}\end{array}$ & $\begin{array}{l}\text { Bivalve shell } \\
\text { (Hiatella arctica) }\end{array}$ & $\begin{array}{l}70^{\circ} 57^{\prime} 34 \mathrm{~N} \\
24^{\circ} 06^{\prime} 49 \mathrm{~W}\end{array}$ & $10140 \pm 100$ & 9590 & $\begin{array}{l}\text { Lollandselv, Jameson Land. Paired } \\
\text { shells } 59 \mathrm{~m} \text { a.s.1. in prograding delta } \\
\text { built to marine limit at } 70 \mathrm{~m} \text { a.s.l. }\end{array}$ & This work \\
\hline $\begin{array}{l}\text { AAR- } \\
2107^{3)}\end{array}$ & $\begin{array}{l}\text { Plant remains (Polytri- } \\
\text { chum s.l., Saxifraga oppo- } \\
\text { sitifolia leaves, Oxyria } \\
\text { digyna fruits) }{ }^{2)}\end{array}$ & $\begin{array}{l}70^{\circ} 57^{\prime} 34 \mathrm{~N} \\
24^{\circ} 06^{\prime} 49 \mathrm{~W}\end{array}$ & $9420 \pm 100$ & & $\begin{array}{l}\text { Lollandselv, Jameson Land. Washed } \\
\text { out plant detritus from same bed } \\
\text { as above }\end{array}$ & This work \\
\hline $\mathrm{K}-3109$ & $\begin{array}{l}\text { Bivalve shells } \\
\text { (Mya truncata) }\end{array}$ & $\begin{array}{l}70^{\circ} 30^{\prime} \mathrm{N} \\
23^{\circ} 27^{\prime} \mathrm{W}\end{array}$ & $10160 \pm 145$ & 10010 & $\begin{array}{l}\text { Fynselv, Jameson Land. Paired shells } \\
\text { from homogenous sand } 40 \mathrm{~m} \text { a.s.l. } 2 \mathrm{~m} \\
\text { below delta-surface. Although well pre- } \\
\text { served, the shells are not in situ, and their } \\
\text { relation to the marine limit at c. } 55 \mathrm{~m} \text { is } \\
\text { uncertain }\end{array}$ & Funder 1990b \\
\hline $\mathrm{K}-1916$ & Gyttja (bulk) & $\begin{array}{l}70^{\circ} 52^{\prime} \mathrm{N} \\
22^{\circ} 27^{\prime} \mathrm{W}\end{array}$ & $9630 \pm 120$ & & $\begin{array}{l}\text { Klitdal. Lower } 3 \mathrm{~cm} \text { of clay gyttja w. } \\
\text { autochtonous moss remains in lake } \\
\text { sediment core (bulk), at lower boundary } \\
\text { of organic sediment }\end{array}$ & Funder 1978 \\
\hline $\mathrm{K}-1915$ & $\begin{array}{l}\text { Bivalve shells (Hiatella } \\
\text { arctica, Mya truncata) }\end{array}$ & $\begin{array}{l}71^{\circ} 21^{\prime} \mathrm{N} \\
24^{\circ} 50^{\prime} \mathrm{W}\end{array}$ & $9900 \pm 120$ & 9750 & $\begin{array}{l}\text { Kjove Land. Shells in life position in } \\
\text { glacimarine silt w. dropstones } 97-100 \mathrm{~m} \\
\text { a.s.l. The sequence coarsens upwards } \\
\text { into littoral sand up to } 107 \mathrm{~m} \text {. The sand } \\
\text { forms a terrace sloping up to the local } \\
\text { marine limit at } 110 \mathrm{~m} \text {. Above this, the } \\
\text { apex of the terrace is outwash in front of } \\
\text { the youngest Milne Land stade moraines. }\end{array}$ & Funder 1978 \\
\hline $\mathrm{Lu}-3284$ & $\begin{array}{l}\text { Bivalve shells ( } M y a \\
\text { truncata) }\end{array}$ & $\begin{array}{l}71^{\circ} 04^{\prime} \mathrm{N} \\
24^{\circ} 03^{\prime} \mathrm{W}\end{array}$ & $7860 \pm 100$ & 7310 & $\begin{array}{l}\text { Depotelv, Jameson Land. In sand in } \\
\text { coastal cliff, } 1 \mathrm{~m} \text { below terrace top } \\
\text { at } 5 \mathrm{~m} \text { a.s.l. }\end{array}$ & $\begin{array}{l}\text { Ingólfsson et al. } \\
1994\end{array}$ \\
\hline Lu-3282 & $\begin{array}{l}\text { Bivalve shells ( } M y a \\
\text { truncata) }\end{array}$ & $\begin{array}{l}70^{\circ} 54^{\prime} 49 \mathrm{~N} \\
24^{\circ} 12^{\prime} 26 \mathrm{~W}\end{array}$ & $9420 \pm 110$ & 8870 & $\begin{array}{l}\text { Lollandselv, Jameson Land. In situ } \\
\text { shells in clayey silt } 19 \mathrm{~m} \text { a.s.l. below } \\
\text { terrace at } 21 \mathrm{~m}\end{array}$ & $\begin{array}{l}\text { Ingólfsson et al. } \\
1994\end{array}$ \\
\hline AAR-644 & $\begin{array}{l}\text { Bivalve shell (Hiatella } \\
\text { arctica) }\end{array}$ & $\begin{array}{l}\text { Same as } \\
\text { above }\end{array}$ & $9670 \pm 180$ & 9120 & $\begin{array}{l}\text { Lollandselv, Jameson Land. In situ } \\
\text { shells in pebbly sand at } 17.5 \mathrm{~m} \text { in same } \\
\text { section as above }\end{array}$ & $\begin{array}{l}\text { Ingólfsson et al. } \\
1994\end{array}$ \\
\hline $\mathrm{Lu}-3283$ & $\begin{array}{l}\text { Bivalve shells ( } M y a \\
\text { truncata) }\end{array}$ & $\begin{array}{l}70^{\circ} 56^{\prime} 11 \mathrm{~N} \\
24^{\circ} 12^{\prime} 20 \mathrm{~W}\end{array}$ & $8710 \pm 100$ & 8060 & $\begin{array}{l}\text { Lollandselv, Jameson Land. Below } \\
\text { surface of small delta at } 27 \mathrm{~m} \text { a.s.l. }\end{array}$ & $\begin{array}{l}\text { Ingólfsson et al. } \\
1994\end{array}$ \\
\hline AAR-643 & $\begin{array}{l}\text { Bivalve shell (Chlamys } \\
\text { islandica) }\end{array}$ & $\begin{array}{l}70^{\circ} 54^{\prime} 48 \mathrm{~N} \\
24^{\circ} 12^{\prime} 58 \mathrm{~W}\end{array}$ & $8730 \pm 130$ & 8180 & $\begin{array}{l}\text { Lollandselv, Jameson Land. Deep water } \\
\text { fauna from prodeltaic laminated sand } \\
\text { and silt at } 30 \mathrm{~m} \text { a.s.l. }\end{array}$ & $\begin{array}{l}\text { Ingólfsson et al. } \\
1994\end{array}$ \\
\hline $\mathrm{Lu}-3400$ & $\begin{array}{l}\text { Bivalve shells (Hiatella } \\
\text { arctica, Mya truncata) }\end{array}$ & $\begin{array}{l}70^{\circ} 44^{\prime} \mathrm{N} \\
24^{\circ} 06^{\prime} \mathrm{W}\end{array}$ & $9760 \pm 110$ & 9210 & $\begin{array}{l}\text { Jyllandselv, Jameson Land. From } \\
\text { glaciomarine diamicton w. clay laminae } \\
\text { at } 33 \mathrm{~m} \text { a.sl. }\end{array}$ & $\begin{array}{l}\text { Ingólfssson et al. } \\
1994\end{array}$ \\
\hline
\end{tabular}




\begin{tabular}{|c|c|c|c|c|c|c|}
\hline Lab. No. & Dated material & Lat./Longt & . ConvBP & RcorrBP') & & Source \\
\hline $\mathrm{T}-10382$ & $\begin{array}{l}\text { Bivalve shells (Astarte } \\
\text { elliptica) }\end{array}$ & & $8965 \pm 110$ & 8845 & $\begin{array}{l}\text { Jyllandselv, Jameson Land. In situ shells } \\
\text { from silt with pebbles at } 35 \mathrm{~m} \text { a.s.l. }\end{array}$ & $\begin{array}{l}\text { Lyså \& Landvik } \\
1994\end{array}$ \\
\hline AAR-995 & $\begin{array}{l}\text { Bivalve shell (Astarte } \\
\text { elliptica) }\end{array}$ & $\begin{array}{l}70^{\circ} 55^{\prime} \mathrm{N} \\
24^{\circ} 13^{\prime} \mathrm{W}\end{array}$ & $9310 \pm 105$ & 8760 & $\begin{array}{l}\text { Jyllandselv, Jameson Land. In situ shells } \\
\text { from massive silt w. pebbles } 40 \mathrm{~m} \text { a.s.l. }\end{array}$ & $\begin{array}{l}\text { Ingólfsson et al. } \\
1994\end{array}$ \\
\hline AAR-965 & periostracum (Astarte sp.) & $\begin{array}{l}70^{\circ} 41^{\prime} \mathrm{N} \\
24^{\circ} 58^{\prime} \mathrm{W}\end{array}$ & $9510 \pm 150$ & 8960 & $\begin{array}{l}\text { Lake Boksehandsken, Jameson Land. } \\
\text { Periostracum from laminated clay } 1.5 \mathrm{~m} \\
\text { below isolation contact in lake sediment } \\
\text { core. Lake water level } 55 \mathrm{~m} \text { a.s.1. }\end{array}$ & $\begin{array}{l}\text { Björck et al. } \\
\text { 1994b }\end{array}$ \\
\hline
\end{tabular}

1) Corrected for a reservoir effect of $-550 \mathrm{yr}$ (Tauber \& Funder 1975)

2) Identified by $O$. Bennike

3) Used also for construction of uplift curve

$\mathrm{ka}$, and Landvik (1994) suggested that maximum ice coverage in northern East Greenland persisted until 10 $\mathrm{ka}$. South of this, from Hochstetter Forland and southwards, recession began earlier and LGM may date from before $15 \mathrm{ka}$, as discussed below. In these areas the large moraines of the Milne Land Stade mark the $10 \mathrm{ka}$ ice margin. These moraines are accompanied by a weathering boundary and a zone of high marine limits, and are interpreted as formed during a readvance of fjord glaciers, lasting from 10.3 to $9.5 \mathrm{ka}$ (Hjort 1981a). This implies that recession before that had proceeded behind this line.

Onshore studies at the mouth of Scoresby Sund have shown that the large grounded outlet glacier which filled the fjord basin during LGM, the Flakkerhuk stade, was thin and less than $400 \mathrm{~m}$ thick at the fjord mouth (Mangerud \& Funder 1994; Tveranger, HoumarkNielsen, Løvberg \& Mangerud 1994). It probably had its front on the "Kap Brewster sedimentary ridge"; a 20 $\mathrm{km}$ wide, $175 \mathrm{~m}$ high, and more than $30 \mathrm{~km}$ long ridge of Quaternary sediments which has been located from air gun and bathymetric data at the fjormouth (Fig. 4 and Dowdeswell, Uenzelmann-Neben, Whittington \& Marienfeld 1994). This is in agreement with ice core studies on a local ice cap which showed that the Inland Ice during LGM was drained through the deep fjord troughs and never invaded the adjacent mountain plateaus at c. $2000 \mathrm{~m}$ a.s.1. (Johnsen, Clausen, Dansgaard, Gundestrup, Hansson, Jonsson, Steffensen \& Sveinbjørnsdottir 1992). Recent seismic studies have indicated that a similar but smaller moraine-like ridge occurs at the mouth of Kong Oscar Fjord to the north of Scoresby Sund, but is lacking from other fjords (Hubberten, Grobe, Jokat, Melles, Niessen \& Stein 1995). Coring on the shelf and its edge at the mouth of Scoresby Sund and at Hochstetter Forland show maximum fluxes of terrigenous material and pulses of IRD indicating the presence of ice bergs and melt water from glacier fronts on the shelf between 16 and $21 \mathrm{ka}$. This was correlated with LGM in Scoresby Sund, the Flakkerhuk stade (Nam, Stein, Grobe \& Hubberten 1995; Stein, Nam, Grobe \& Hubberten in press). The history of the glacier in Scoresby Sund is discussed further below.

South of Scoresby Sund, at the termination of the Kangerlussuaq trough (Fig. 1), bathymetrical mapping showed "fresh" moraines and ice marginal deposits which were associated with LGM (Sommerhoff 1973, 1975). Recently, coring and seismic surveys in this area have indicated that ice recession from the outer shelf began shortly before $13.6 \mathrm{ka}$ and proceeded rapidly, leaving the $250 \mathrm{~km}$ broad shelf free of ice at c. $10 \mathrm{ka}$ (Mienert, Andrews \& Milliman 1992; Williams 1993; Andrews, Jennings, Cooper, Williams \& Mienert in press).

Therefore, the East Greenland coast displays two distinctly different types of glacier behaviour during LGM: In the southern parts, the Inland Ice expanded onto the wide shelf and reached the outer shelf break; but from Scoresby Sund and northwards glaciation was restricted to outlet glaciers which filled the fjord troughs but left the adjacent uplands free of ice cover and had their snouts on the inner shelf. Northwards to Hochstetter Forland deglaciation of the inner shelf apparently began at c. $15 \mathrm{ka}$, and by $10 \mathrm{ka}$ the shelves and outer fjords were ice free. To the north of this, recession did not begin until this time.

\section{Scoresby Sund between 16 and $10 \mathrm{ka}$}

The Scoresby Sund drainage system is the largest single outlet from the eastern margin of the Inland Ice. Owing to work during the PONAM Project this area has the most detailed record of events during and after LGM (Funder, Hjort \& Landvik 1994), and current field work has added to this. The position of ice margins and key ${ }^{14} \mathrm{C}$ dates are shown on Fig. 4, and details of the ${ }^{14} \mathrm{C}$-dates are given in Table 1.

As noted above, a large outlet glacier filled the fjord system during LGM probably with its front on the Kap Brewster sedimentary ridge, between 16 and $21 \mathrm{ka}$ (Fig. 
4). Six thousand years later, during the Milne Land stade, the glacier fronts had receded c. $150 \mathrm{~km}$ and uncovered the outer fjord basin. Current studies on western Jameson Land show that the glacial history during and after LGM began when the glacier in Scoresby Sund ran along the present coastline and deposited proglacial sediments along the margin and in blocked river valley basins. Next, during the peak of glaciation, the glacier expanded inland over the ice dammed lake basins, up to 15 kilometres from the coast and deposited thin and discontinuous till over the area. After this, the ice melted, maybe with lakes dammed against its margin. In the final collapse much of the land based ice was transformed to dead-ice as seen from the numerous kames. The retreating ice front was followed by marine water, and the present pattern of fluvial drainage was established with marine limit at c. $70 \mathrm{~m}$ above sea level in western Jameson Land. During the Milne Land stade the fjord glaciers advanced to positions on the western margin of the Scoresby Sund basin, but did not reinvade western Jameson Land (Fig. 4).

New ${ }^{14} \mathrm{C}$-dates from Lollandselv, western Jameson Land, provide evidence on the last stage in this history. Paired shells of Hiatella arctica were found some metres below the $61 \mathrm{~m}$ top of a sloping terrace in gently inclined sandbeds, which coarsen towards the top of the terrace at $70 \mathrm{~m}$ a.s.l., which is also the local marine limit. The sediments are therefore interpreted as the distal part of the delta and thereby contemporaneous with the marine limit. The shells gave a reservoir-corrected age of $9590 \pm 100$ yr BP. From the same beds, washed out remains of high arctic plants were dated to $9420 \pm 100 \mathrm{yr} \mathrm{BP}$ (samples AAR-1829 and 2107, Table 1). The two ages support each other and indicate that the age of the delta, and the local marine limit, was 9.5 $\pm 0.2 \mathrm{ka}$. At this time very extensive delta-construction took place on Jameson Land, indicating both a rich sediment supply and probably also sea level stillstand for some centuries.

However, deglaciation and marine invasion in Scoresby Sund happened before this. This appears from ${ }^{14} \mathrm{C}$ dates obtained on foraminifer faunas from cores in Scoreby Sund (Dowdeswell et al. 1994). They show that deglaciation took place before $10.2 \mathrm{ka}$ (Table 1). Similarly, a ${ }^{14} \mathrm{C}$-age of $9.8 \mathrm{ka}$ obtained for in situ shells in front of the youngest moraines of the Milne Land stade $50 \mathrm{~km}$ up fjord from Lollandselv, shows that the glacier front had already been oscillating in this area for some time before this (Fig. 4 and Table 1). Consequently, western Jameson Land had been ice free at least some centuries before the formation of the marine limit.

From the lithology of sediment cores in the deep part of the Scoresby Sund basin Marienfeld (1991) and Dowdeswell et al. (1994) suggested that the basin became ice free during the Allerød (c. 12-11 ka). A boulder rich diamicton shows that there were calving ice bergs, and therefore seasonally open water. During the Younger Dryas (c. 11-10 ka) the fjord was covered by permanent sea ice, as interpreted from a bed of lami- nated fossil-free mud. This ended with the transition to homogenous sandy mud with dropstones and foraminifer faunas, indicating that at c. $10 \mathrm{ka}$ the fjord was again seasonally ice free (Table 1). According to this interpretation Jameson Land therefore became ice free during the Allerød and the lack of ${ }^{14} \mathrm{C}$-dates from the Younger Dryas period must be ascribed to the harsh climatic conditions, such as seen in the lack of benthic faunas in cores. This is supported by ${ }^{14} \mathrm{C}$-dates from pre-Early Holocene lake sediments in the area which is assumed to have been ice free. The ages range unsystematically from 15 to $22 \mathrm{ka}$, indicating that the organic component in the sediment is varying amounts of Pre-Quaternary coal washed out from the bare soils of the surrounding terrain surface (Björck et al. 1994a; Björck, Bennike, Ingólfsson, Barnekow, Penney 1994b).

\section{Uplift history}

\section{Marine limits}

Figure 3 shows isolines for the Late Weichselian-Early Holocene marine uplift in Greenland. The observations, show a pattern of coast-parallel elongated domes with high marine limits separated by coastal stretches with little uplift.

The three major domes are located over the Sisimiut district in West Greenland with maximum limits of 140 $\mathrm{m}$, the Scoresby Sund region in East Greenland with maximum altitudes of c. $135 \mathrm{~m}$, and Hall Land in North Greenland, with maximum limits of c. $130 \mathrm{~m}$; a fourth dome may be present over central Peary Land, but the field observations are too sparse to be definitive. In West, East and North Greenland the domes coincide with the location of the Taserqat, Milne Land and Warming Land stade moraines which have been considered to mark a period of stillstand or readvance at c. $9.5 \mathrm{ka}$, which heralded two millenia of rapid retreat and melting of ice on land. In West and North Greenland this lies close to the outer coast, whereas it is c. $150 \mathrm{~km}$ up-fjord in East Greenland. The fourth dome over Peary Land, may also reflect such a mid-fjord ice margin position, but the glaciation history in this area is poorly known.

Low-uplift areas with maximum uplift around $20 \mathrm{~m}$, occur in Melville Bugt in northwest Greenland and along the southeast Greenland coast. In both of these areas the present Inland Ice margin is close to the outer coasts. This shows that either the ice cover over land has not changed significantly since LGM, or there has been a considerable build up of ice during the Late Holocene. Field observations from these two regions are too scanty to give an answer, but the latter possibility is supported by the circumstance that exactly these two regions today have the largest mass balance gain (Olesen, Weidick, Reeh, Thomsen, Braithwaite \& Bøggild 1995). In the Kangerlussuaq region the low marine limits at c. $40 \mathrm{~m}$ in the coastal zone are com- 
bined with the most extensively glaciated shelf in Greenland.

\section{Age of the marine limit}

In most areas the marine limit was formed immediately after the deglaciation, and this has traditionally been regarded to be the case in all parts of the ice free land. However, shells and other organic material are usually very sparse close to the marine limits, and its dating has often been derived by extrapolation from ages on bivalve shells from some distance below the marine limit. If the marine limit was developed after a period of transgression, this method leads to erroneous estimates. Recent dating-results indicate that this may be the case in some areas.

Figure 5 shows the uplift in the Scoresby Sund area. The curve from western Jameson Land has been constructed from shell-dates from a c. $30 \mathrm{~km}$ long coastal stretch, and the general depth requirements of the faunas have been considered (Table 1). However, bivalves only reflect water depths in a general way, and the curves are drawn as straight lines which represent the average uplift after formation of the marine limit. The top of the curve from western Jameson Land are the dates for the marine limit at Lollandselv mentioned above, and it is suggested that this marks a period of stillstand. The second highest sample which is also important for defining the slope of the curve is a shell-periostracum from a nearby lake core. This sample was also used by Björck et al. (1994b) in their uplift curve from this area, but without reservoir correction. The curve implies that the average rate of uplift from c. 7 to c. 9.5 ka was c. $2.4 \mathrm{~cm} /{ }^{14} \mathrm{C}$-yr. This is similar to the result obtained by Björck et al. (1994b), but the age of the uplift is nearly 500 years younger.

The uplift rate was higher in the area of the $10 \mathrm{ka}$ moraine, $50 \mathrm{~km}$ further up fjord. This is shown by a comparison with a previous curve from this area (Fig. 5). Essential in this curve is the ${ }^{14} \mathrm{C}$-date mentioned above of $9,750 \pm 120 \mathrm{yrBP}$ on in situ shells at $100 \mathrm{~m}$ a.s.l. in glaciomarine sediments at the base of a coarsening upward sequence (Table 1, sample K-1915). The sediments were deposited below wave base and the mollusc-fauna is not littoral. The age is therefore interpreted to represent the marine limit at $110 \mathrm{~m}$ (Funder 1978). From this, the average uplift rate at the $10 \mathrm{ka}$ ice margin was c. $3.7 \mathrm{~cm} /{ }^{14} \mathrm{C}$-yr.

This comparison shows that the marine limit in areas outside the $10 \mathrm{ka}$ ice margin is younger than the local deglaciation, and the uplift rate slower. The 250 yr agedifference between the two dates may indicate that the age of the marine limit decreases slightly towards the outer coast.

On western Disko Ingólfsson et al. (1990) noted that prograding deltas were graded to the marine limit, which was dated to $9.2 \mathrm{ka}$, but the delta construction probably began before $9.4 \mathrm{ka}$ at lower sea level. In the same area,

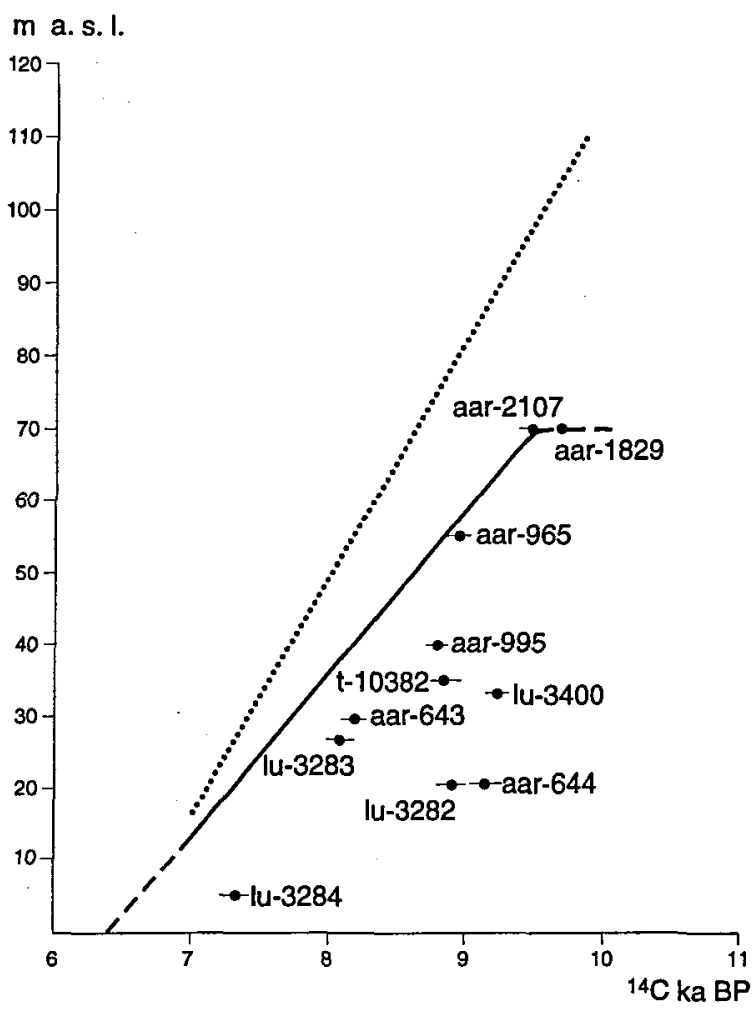

Fig. 5. Holocene uplift in Scoresby Sund. The curve from western Jameson Land (thick line) is based on the dates shown on the figure and listed in Table 1. The stippled curve shows uplift in the area of the Milne land stade moraines and is reproduced from Funder (1978).

Bennike (1994) found that the marine limit on an island off the coast had an age of c. $9.1 \mathrm{ka}$. He interpreted this to show that the glacier in Disko Bugt had been lingering on until then. However, at $9.1 \mathrm{ka}$ this large embayment had been free of ice for more than 400 years according to the results mentioned above by Ingólfsson et al. (1990). The apparent conflict is solved if it is accepted that the marine limit on the coastal island is at least 400 years younger than the local deglaciation.

In southeastern North Greenland, Hjort (in press) found that shallow marine sediments at low altitudes pre-date the formation of the maximum marine limit, and show that sea level was rising from 10.8 to the marine limit at c. $9.1 \mathrm{ka}$.

From separate parts of Greenland recent evidence, therefore, indicate that marine limits outside the $10 \mathrm{ka}$ ice margin become younger and not older, as has been the traditional interpretation. The pattern of marine limits and their age as suggested by these results is shown schematically on Fig. 6 , and is similar in outline although not in timing, to conditions on the margins of the large ice sheets, such as in western Norway (e.g. Svendsen \& Mangerud 1987). One implication of the 
results from Greenland is that the uplift to a large extent is a response to the rapid melting that began in all parts shortly after $10 \mathrm{ka}$, and within c. 2 millenia exposed all the presently ice free land areas. The weaker uplift in areas outside the $10 \mathrm{ka}$ ice margin was partly compensated by eustatic sea level rise. The rate of eustatic sea level rise declined over this period from a peak of c. $2.8 \mathrm{~cm} /{ }^{14} \mathrm{C}$-yr at $9.5 \mathrm{ka}$ to c. $1 \mathrm{~cm} /{ }^{14} \mathrm{C}$-yr at 9 ka according to the Barbados sea level curve (Fairbanks 1990).A further implication is that the deglaciation prior to $10 \mathrm{ka}$ caused only a small isostatic response, probably because most of the ice burden which was cleared away came from the shelf and major inlets and was replaced by sea water.

\section{Distribution of ${ }^{14} \mathrm{C}$-ages}

Figure 7 shows the age-distribution in an unbiassed population of $1027{ }^{14} \mathrm{C}$-dates from terrestrial and marine biotopes in Greenland. The ages come from a database of Greenland ${ }^{14} \mathrm{C}$-dates which is under construction at The Geological Museum, and gives evidence of the invasion of life. Most of the samples are from shallow marine environments (shells in raised marine deposits). Another large group is from terrestrial biotopes (mostly organic lake sediments). Finally, a number of dates have recently been published from the shelf and deep fjords in East Greenland (foraminifer faunas from cores). The dates are distributed rather evenly overWest, North, and East Greenland and show, if the ages from the East Greenland shelf are excluded, the same distribution in all areas.

The most remarkable features are the sharp rise in shallow marine and terrestrial dates following shortly after $10 \mathrm{ka}$ and especially around 9.5 , and the extreme sparsity of ages between 10 and $18 \mathrm{ka}$. If the samples from the shelf are excluded, there are only 7 samples from all parts of the country in this time interval. (A larger number of dates from this interval come from minerogenic lake sediments in East and West Greenland and have been shown to be too old (Björck et al. 1994a, Ingolfsson et al. 1990), while a few shell samples in North Greenland are mixtures of faunas of different ages, as shown by amino acid analyses or other indications (Funder 1982, Blake 1987). Therefore these ages have been excluded from the statistics. Considering this, some of the seven remaining samples may also be erroneous since there is no control of these). As shown above, the sparsity of ages older than the Preboreal can to some extent be explained by the harsh climate and low organic production. However, in general it reflects the uncovering from ice on the fjords and adjacent land areas at c. $9.5 \mathrm{ka}$, as shown also by the deglaciation histories described above. It is noticeable that this happened at the same time in all parts, both in areas with advective climate, such as west Greenland, and in areas with insolation-dominated climate, such as northernmost Greenland. This indicates that the driving factor in the rapid melting was primarily increased summer-insolation which peaked shortly after $10 \mathrm{ka}$ (COHMAP members 1988).

\section{Discussion, implications}

The picture of LGM ice distribution evoked here has, even with its poor age control and sometimes speculative ice margins, some implications for the ice age en-

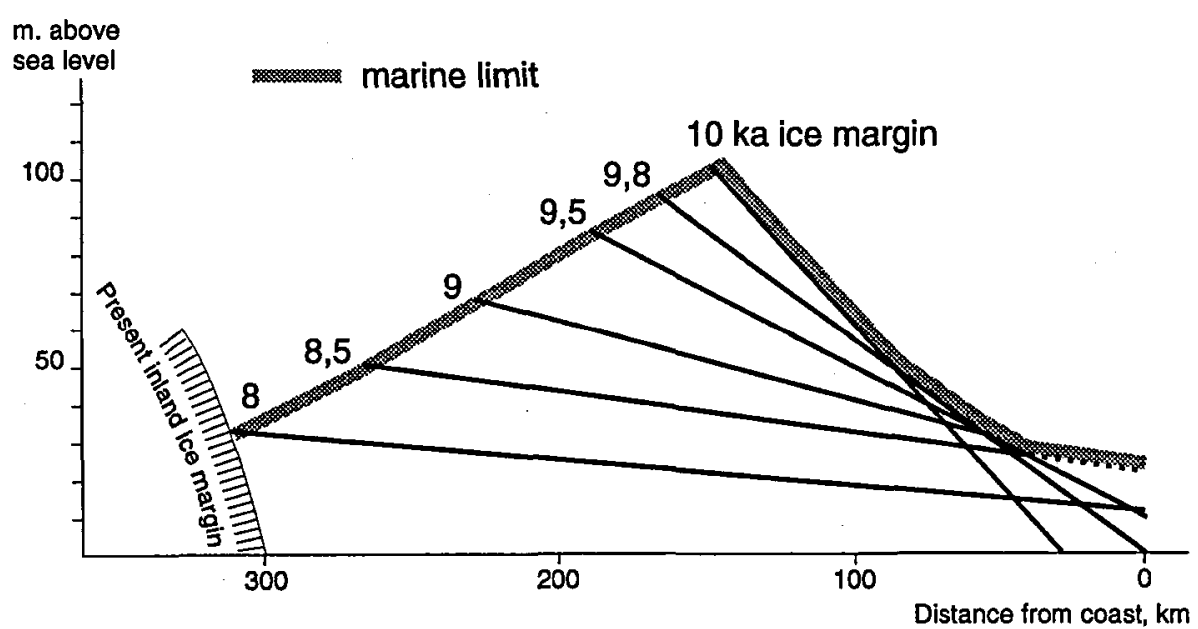

Fig. 6. Schematic representation of the age and altitudes of marine limits in a cross section of the Scoresby Sund region, from coast to Inland Ice. Probably also representative for Disko Bugt and other areas with early deglaciation. Schematic and not true to scale. Shorelines older than $10 \mathrm{ka}$ are not included because there are no good field observations in Greenland. 


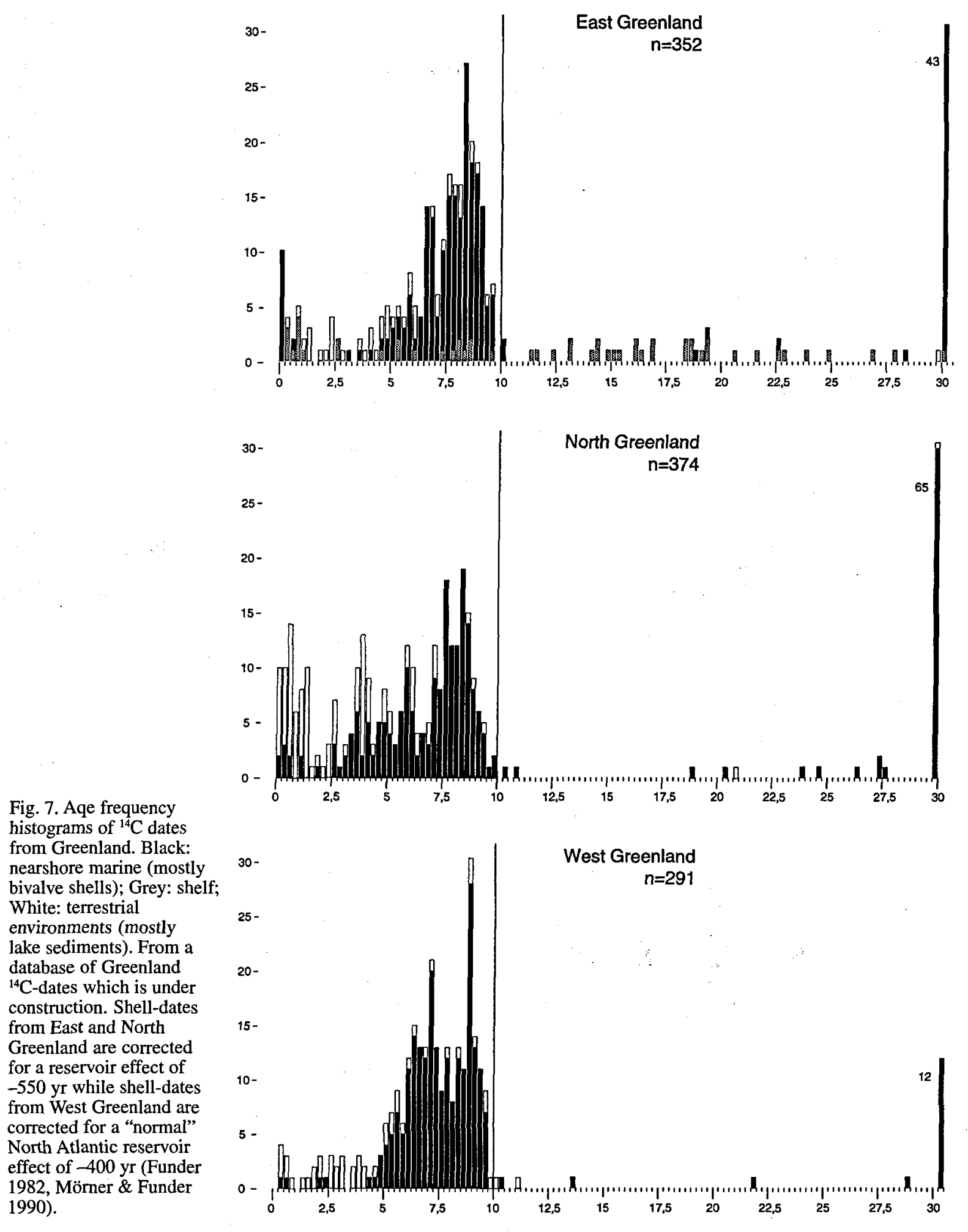



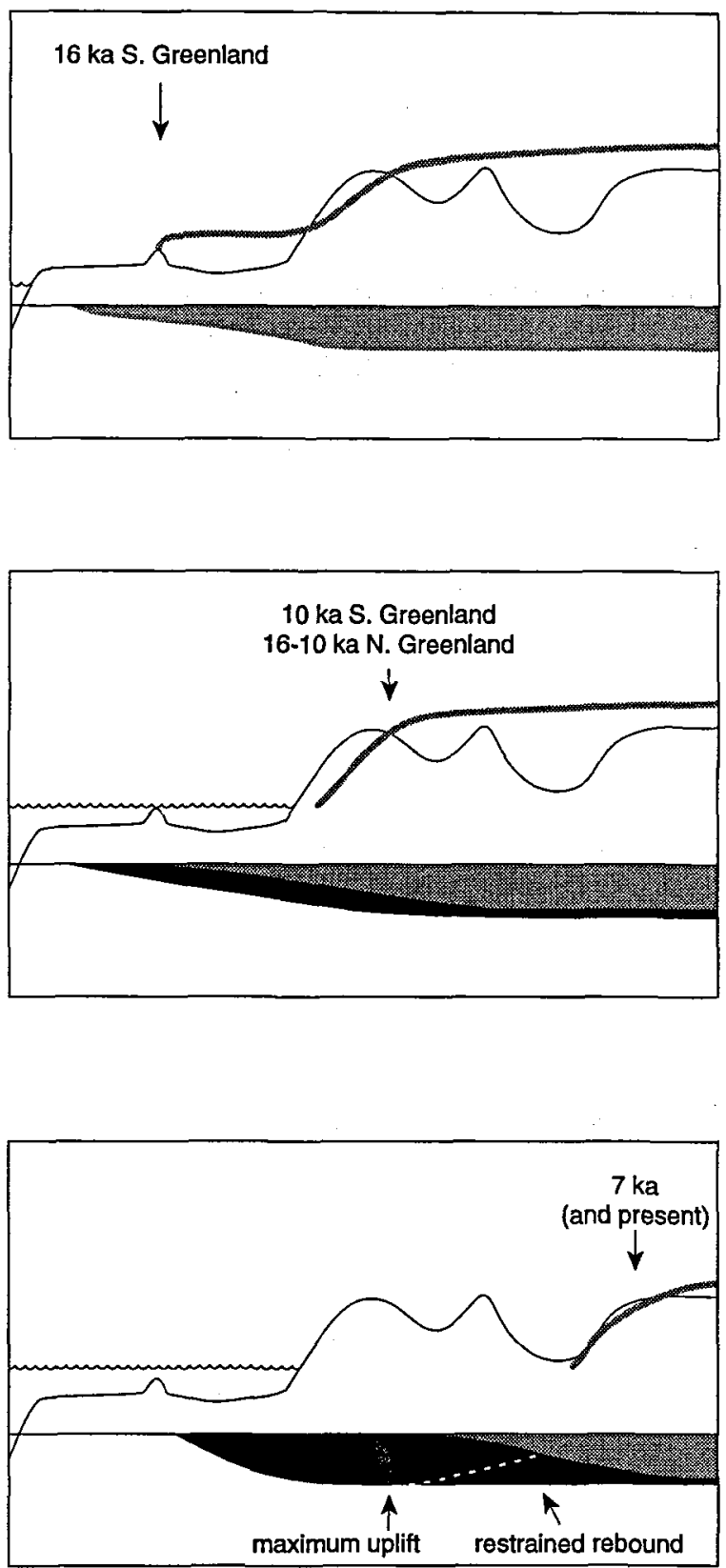

Fig. 8. A schematic model for the two-step deglaciation and uplift in Greenland since LGM. Thick grey line: ice cover. wavy line: sea level. Grey: isostatic submergence. Black: isostatic rebound since previous stage. Restrained rebound is uplift during the melting while ice still covers the ground. vironment which can be tested in future field work. Apparently it was only in the southern parts of Greenland, south of Lat. $69^{\circ}-72^{\circ} \mathrm{N}$, that the ice sheet was able to expand onto the shelf, and apparently it was only in south-east Greenland that it reached the shelf edge. In northern Greenland, north of $69^{\circ}-72^{\circ}$, outlet glaciers filled up the fjord basins and piedmont glaciers from the coastal mountains may have covered the intervening coastline, but the glaciers did not expand onto the shelf (Fig. 2). This pattern implies that in North Greenland the climate was dry and cold with little accumulation and little melting, while southern Greenland had higher accumulation and more oceanic climate. This pattern is a reflection of the present day accumulation on the ice sheet (Ohmura \& Reeh 1991, Olesen et al. 1995). This shows a maximum of $1000-1500 \mathrm{~mm}$ water equivalent over the south-east, and a minimum of 100-150 mm over north-east Greenland. Therefore, decreased ablation alone could cause massive growth of the ice sheet in the south-east, and this may have played an important role in the LGM growth phase. In East Greenland the transition from shelf to fjord glaciation was abrupt between Kangerlussuaq and Scoresby Sund. This implies that the Greenland and Iceland ice sheets formed a barrier that blocked the northwards running cyclone tracks through Denmark Strait and caught most of the precipitation coming from the south, while the northern part of the east coast was starved of moisture. In west Greenland, the suggested lobate ice front on the shelf could only be maintained if there was a constant discharge from the ice margin by calving through the transverse channels into Davis Strait and Baffin Bay. This applies also to the front of the Smith Sound ice stream, and suggests that there was seasonally open water in these areas also during LGM. Some support for this contention is found in a deep sea core from Davis Strait, which shows seasonally open water at LGM (De Vernal, Turon, \& Guiot 1993).

The timing of LGM in Greenland is known only from the Scoresby Sund area, where it took place between 21 and $16 \mathrm{ka}$ (Stein et al. in press). Although the evidence is sparse, it indicates that the growth and decline of the Greenland ice sheet was in phase with the neighbouring Barents Sea ice sheet, and the northeastern sector of the Laurentide ice sheet which also began to decline at 16-15 ka (Elverhøi, Fjeldskaar, Solheim, Nyland-Berg \& Russwurm 1993; Elverhøi, Andersen, Dokken, Søflaten, Rørnes, Hald, Hebbeln, Spielhagen, Svendsen \& Forsberg in press; Andrews, Tedesco, Briggs \& Evans 1994).

The deglaciation took place in two discrete steps, as shown schematically in Fig. 8. First, the shelf and major inlets were cleared by calving; then the narrow fjords and land areas were exposed by calving and melting (Fig. 8). The first step probably began at c. $15 \mathrm{ka}$, it affected mainly the southern areas, and in all areas it ended before $10 \mathrm{ka}$. The detailed history is not well known, but it has been suggested that Scoresby Sund became ice free during the Allerød and a similar argu- 
ment has been presented for parts of the East Greenland shelf further south (Andrews et al. in press), and may also apply to Disko Bugt, the outer Independence Fjord and other major inlets.

However, one of the remarkable features in this reconstruction is that areas with no shelf glaciation and no major inlets apparently saw little change during this first deglaciation phase (Fig. 2). Also, the study of weathering limits indicate that on land the ice surface was lowered very little during this period (Kelly 1985). This shows that the break up of the ice sheet was caused primarily by sea level rise, which destabilised the marine based ice, similar to the fate of the marine based Barents Sea ice sheet at this time (Elverhøi et al. 1993, in press), and melting played only a minor role during this phase. Therefore, during this phase ice was removed mainly by calving from the shelf and major inlets, and was to a large extent replaced by water. On land, the ice burden remained almost constant, and this explains why there was only a slight isostatic response to the removal of ice in this phase (Fig. 8).

The second step in the deglaciation process began at c. $10 \mathrm{ka}$. This time the time control is much better and shows that the rapid glacier retreat in all parts of the country began with a readvance, the Taserqat, Warming Land, and Milne Land stades of West, North, and East Greenland. The readvance culminated not in the Younger Dryas, but in the Preboreal between 10 and $9.5 \mathrm{ka}$. This is similar to the Gold Cove readvance at the northeastern margin of the Laurentide ice sheet (Kaufman, Miller, Stravers, Manley, \& Duvall 1993). The regionality of this event indicates that it was the ice sheets' immediate reaction to increased precipitation and temperatures at the establishment of the present day pattern of meridional atmospheric circulation, as suggested by Funder \& Hjort (1973) and more recently by Kaufman et al. (1993). Nowhere in Greenland is there evidence for a Younger Dryas readvance of glaciers. This suggests that the climate was too cold and dry for glacier growth.

The Preboreal readvance was followed by rapid glacier recession in all parts. Moraines and outwash from this time occur abundantly, but in most areas the present ice margin location was attained already at $8-7 \mathrm{ka}$. This shows that the retreat was rapid, and the moraines mark short lasting topographically conditioned stillstand or small scale readvances. The abrupt rise in the frequency of ${ }^{14} \mathrm{C}$-dates from this period also shows that land and fjords were uncovered from the ice, and marine and terrestrial biotopes emerged (Fig. 7). The most extensive retreat was in West and North Greenland which are also the most temperature-sensitive parts of the Inland Ice, in the ice volume/temperature change simulations by Letréguilly, Huybrechts \& Reeh (1991). Contrary to the first deglaciation-step, the glacier retreat this time involved not only calving of fjord glaciers but also melting, and it is suggested here that the pattern of Holocene isostatic uplift in Greenland is essentially a response to this unloading (Figs 3,8 ).

\section{Dansk sammendrag}

Rekonstruktioner af den grønlandske Indlandsis' udbredelse under det sidste glacial maximum $(18,000$ år siden) og for 10,000 år siden er blevet konstrueret ud fra en sammenstilling af resultater fra land, suppleret med nyere maringeologiske unders $\varnothing$ gelser fra den $\varnothing$ stgrønlandske shelf og nye resultater fra et løbende projekt i Scoresby Sund. Rekonstruktionerne antyder, at kun i de sydlige egne af Grønland nåede isen ud på shelfen under det sidste glaciale maximum. I de nordlige egne var fjord-bassinerne fyldt af udløb fra Indlandsisen, mens piedmont-gletschere fra kystbjergene dækkede kystlandet; men gletscherne nåede tilsyneladende ikke ud på shelfen.

Opbruddet af isen begyndte sandsynligvis for ca. 15,000 år siden. Under den første fase var det isen på shelfen og i større bugter som Scoresby Sund, Disko Bugt og den ydre Independence Fjord, der brød op og kælvede. Der skete tilsyneladende ikke store forandringer $\mathrm{i}$ isens tykkelse på land og i det nordlige Grønland, hvor der ikke var is på shelfen, skete der tilsyneladende ikke større forandringer overhovedet. Dette tyder på, at den kontrollerende faktor var det stigende havniveau, mens smeltning kun spillede en mindre rolle. For 10,000 år siden begyndte den næste fase i opbruddet. Efter et kortvarigt gletscherfremstød trak fjordgletscherne sig tilbage $i$ alle egne af landet og isen på land smeltede væk, således at det nuværende isfrie land blev blottet i løbet af de næste 2000 år. Dette fremgår af en sammenstilling af mere end $1000{ }^{14} \mathrm{C}$-dateringer fra hele Grønland. I denne fase spiller smeltningen af is en afgørende rolle, sandsynligvis forårsaget af forhøjet solindstråling.

En sammenstilling af $h \varnothing j d e n$ af den marine grænse i Grønland viser at de største højder forekommer i de områder, hvor isranden lå for c. 10,000 år siden. Dette tyder på, at hævningen siden Istiden hovedageligt er forårsaget af den hurtige afsmeltning efter år 10,000. Nyere dateringer understøtter dette ved at vise, at den marine grænse tilsyneladende bliver yngre, når man går fra 10,000 års-isranden og ud mod kysten - og ikke ældre, som hidtil antaget.

\section{Acknowledgments}

Field work in Scoresby Sund was carried out during the PONAM and Arctic Terminations projects, funded by the European Science Foundation and the Danish Research Council. ${ }^{14} \mathrm{C}$-dates for these projects were provided by the AMS $-{ }^{14} \mathrm{C}$ dating Laboratory, University of Aarhus, and its leaders J. Heinemeier and N. Rud are gratefully acknowledged for the willingness to discuss the results, as are the many participants of the PONAM project for discussing various aspects of the ideas outlined in this paper. T. Bredsdorff prepared the 
illustrations and supervised their lay out. O. Bennike, C. Hjort and J. Landvik gave constructive and intelligent comments and advice on the manuscript, as did also the reviewers S. Björck and J. Mangerud.

\section{References}

Andrews, J. T., Jennings, A. E., Cooper, T., Williams, K. M. \& Mienert, J. in press: Late Quaternary sedimentation along fjord to shelf (trough) transect, East Greenland (ca. $68^{\circ} \mathrm{N}$ ). Special Publications of the Geological Society in London.

Andrews, J. T., Tedesco, K., Briggs, W. M. \& Evans, L. W. 1993: Sediments, sedimentation rates, and environments, southeast Baffin Shelf and Northwest Labrador Sea, 8-26 ka. Canadian Journal of Earth Science 31, 90-103.

Bard, E., Fairbanks, R. G. \& Hamelin, B. 1992: How accurate are the U-Th ages obtained by mass spectrometry on coral terraces. in Kukla, G. J. \& Went, E. (eds) Start of a glacial. NATO ASI Series 1, 3, 15-23.

Bennike, O. 1987: Quaternary geology and biology of the Jørgen Brønlund Fjord area, North Greenland. Meddelelser om Grønland, Geoscience 18, 23 pp.

Bennike, O., Hansen, K. N., Knudsen, K. L., Penney, D. N. \& Rasmussen, K. L. 1994: Quaternary marine stratigraphy and geochronology in central West Greenland. Boreas 23, 194-215.

Björck, S.; Bennike, O., Ingólfsson, O, Barnekow, L. \& Penney, D. 1994b: Lake Boksehandsken's earliest postglacial sediments and their paleoenvironmental implications, Jameson Land, East Greenland. Boreas 23, 459-473.

Björck, S., Wohlfahrt, B., Bennike, O., Hjort, C. \& Persson, T. 1994a: Revision of the Early Holocene lake sediment dated chronology and event stratigraphy in Hochstetter Forland, NE Greenland. Boreas 23, 513-525.

Blake, W. 1987: Geological Survey of Canada radiocarbon dates XXVI. Geological Survey of Canada, Paper 86-7, $60 \mathrm{pp}$.

Blake, W. 1992: Holocene emergence at Cape Herschel, eastcentral Ellesmere Island, Arctic Canada: implications for ice sheet configuration. Canadian Journal of Earth Sciences $29,1958-1980$.

Blake, W., Boucherle, M. M., Fredskild, B., Janssens, J. A., \& Smoll, J. P. 1992: The geomorphological setting, glacial history and Holocene development of "Kap Inglefield S $\emptyset$ ", Inglefield Land, North-West Greenland. Meddelelser om Grønland, Geoscience 27, 42 pp.

Bøgvad, R. 1940: Quaternary geological observations etc. in south-east and south Greenland. Meddelelser om Grønland $107,3,42 \mathrm{pp}$.

Brett C. P. and Zarudzki, E. F. K. 1979: Project Westmar, a shallow marine geophysical survey on the West Greenland shelf. Grønlands geologiske Unders $\emptyset$ gelse, report 87, 27 pp.

Brooks C.K. 1979: Geomorphological observations at Kangerlugssuaq, East Greenland. Meddelelser om Grønland, Geoscience 1, 21 pp.

COHMAP members 1988: Climatic changes of the last 18,000 years: observations and model simulations. Science $241,1043-1052$.
Dawes, P. R. 1986: Glacial erratics on the Arctic Ocean margin of North Greenland; implications for an extensive iceshelf. Bulletin of the Geological Society of Denmark 35, 59-69.

De Vernal, A., Turon, J.-L. \& Guiot, J. 1993: Dinoflagellate cyst dustribution in high-latitude marine environments and quantitative reconstruction of sea-surface salinity, temperature, and seasonality. Canadian Journal of Earth Science $31,48-62$.

Dowdeswell, J. A., Uenzelmann-Neben, G., Whittington, R. J. \& Marienfeld, P. 1994: The Late Quaternary sedimentary record in Scoresby Sund, East Greenland. Boreas 23, 294-311.

Elverhøi, A., Fjeldskaar, W., Solheim, A, Nyland-Berg, M. \& Russwurm, L. 1993: The Barents Sea ice sheet - a model of its growth and decay during the last glacial mximum. Quaternary Science Reviews 12, 863-873.

Elverhøi, A., Andersen, E. S., Dokken, T., Søflaten, M., Rørnes, A., Hald, M., Hebbeln, D., Spielhagen, R., Svendsen, J. I. \& Forsberg, C. F. 1995: The growth and decay of the Late Weichselian ice sheet in western Svalbard and adjacent areas based on provenance studies of marine sediments. Quaternary Research 44, 303-316.

Fairbanks, R. G. 1990: The age and origin of the "Younger Dryas climate event" in Greenland ice cores. Paleoceanography 6, 937-948.

Fredskild, B. 1985: The Holocene vegetational development of Tugtuligssuaq and Qeqertat, Northwest Greenland; Meddelelser om Gronland, Geoscience 14, 20 pp.

Fredskild, B. 1992: The Greenland limnophytes - their distribution and Holocene history. Acta botanica Fennica 144, 93-113.

Funder, S. 1978: Holocene stratigraphy and vegetation history in the Scoresby Sund area, East Greenland. Grønlands geologiske Undersøgelse, bulletin 129, $66 \mathrm{pp}$.

Funder, S. 1982: C-14 dating of samples collected during the 1979 expedition to North Greenland. Grønlands geologiske Undersøgelse, report 110, 9-14.

Funder, S. (co-ordinator) 1989: Quaternary geology of the ice free areas and adjacent shelves of Greenland. In: Fulton, R. J. (ed.), Quaternary geology of Canada and Greenland. Geological Survey of Canada, Geology of Canada 1 (also Geological Society of America, The Geology of North America K-1), 741-792.

Funder S. (ed.) 1990a: Late Quaternary stratigraphy and glaciology in the Thule area. Meddelelser om Grønland, Geoscience 22, 63 pp.

Funder, S. 1990b: Descriptive text to Quaternary map of Greenland 1:500,000, Scoresby Sund, sheet 12.24 pp. Copenhagen: Grønlands Geologiske Unders $\emptyset$ gelse.

Funder, S \& Abrahamsen, N. 1988: Palynology in a Polar desert, eastern North Greenland. Boreas 17, 195-207.

Funder, S. \& Hjort, C. 1973: Aspects of the Weichselian chronology in central East Greenland. Boreas 2, 69-84.

Funder, S., \& Hjort, C. 1980: A reconnaissance of the Quaternary geology of eastern North Greenland; Grønlands Geologiske Undersøgelse, report 99, 99-105.

Funder, S., Hjort, C. \& Landvik, J. Y. 1994: The last glacial cycles in East Greenland, an overview. Boreas 23, 283 294.

Funder, S. \& Larsen, H. C. 1989: Quaternary geology of the shelves adjacent to Greenland. In: Fulton, R. J. (ed.) Quaternary geology of Canada and Greenland. Geological 
Survey of Canada, Geology of Canada 1 (also Geological Society of America, The Geology of North America K-1), 769-772.

Funder, S. \& Larsen, O. 1982: Implications of volcanic erratics in Quaternary deposits of North Greenland. Bulletin of the Geological Society of Denmark 31, 57-61.

Håkansson, E., Birkelund, T., Heinberg, C., Hjort, C., Mölgaard, P. \& Schack Pedersen, S. 1993: The Kilen expedition 1985. Bulletin of the Geological Society of Denmark 40, 9-32.

Hjort, C. 1979: Glaciation in northern East Greenland during the Late Weichselian and Early Flandrian. Boreas 8, 281-296.

Hjort, C. 1981a: A glacial chronology for northern East Greenland. Boreas 10, 259-274.

Hjort, C. 1981b: Quaternary geology in northeasternmost Greenland. In Schytt, V., Boström, K. \& Hjort, C. (eds): Geoscience during the Ymer-80 expedition to the Arctic. Geologiska Föreningens i Stockholm Förhandlingar 103, 109-119.

Hjort, C. 1981c: Present and middle Flandrian coastal morphology in Northeast Greenland. Norsk geografisk Tidsskrift 35, 197-207.

Hjort, C. in press: Glaciation, climate history, changing marine levels and the evolution of the northeast water polynya. Journal of Marine Systems.

Hjort, C. and Björck, S. 1984: A re-evaluated chronology for northern East Greenland. Geologiska Föreningens i Stockholm Förhandlingar 105, 235-243.

Houmark-Nielsen, M., Hansen, L., Jørgensen, M. E. \& Kronborg, C. 1994: Stratigraphy of a Late Pleistocene icecored moraine at Kap Herschell, northeast Greenland. Boreas 23, 505-513.

Hubberten, H, Grobe, H., Jokat, W., Melles, M., Niessen, F. \& Stein, R. 1995: Glacial history of East Greenland explored. EOS, Transactions of the American Geophysical Union 76, 350 and 356.

Ingólfsson, O., Frich, P., Funder, S. and Humlum, O. 1990: Paleoclimatic implications of an early Holocene glacier advance on Disko Island, West Greenland. Boreas 19, 297311.

Ingólfsson, O., Lyså, A., Funder, S., Möller, P. \& Björck, S. 1994: Late Quaternary glacial history of the central west coast of Jameson Land, East Greenland. Boreas 23, 447459.

Johnsen, S. J., Clausen, H. B., Dansgaard, W., Gundestrup, N. S., Hansson, M., Jonsson, P., Steffensen, J. P. \& Sveinbjørnsdottir, A. E. 1992: A "deep" ice core from East Greenland. Meddelelser om Grønland, Geoscience 29, 22 pp.

Kaufman, D., Miller, G. H., Stravers, J. A., Manley, W. F. \& Duvall, M. L. 1993: Abrupt early Holocene (9.9-9.6 ka) ice-stream advance at the mouth of Hudson Strait, Arctic Canada. Geology 21, 1063-1066.

Kelly, M. 1985: A review of the Quaternary geology of western Greenland. In Andrews, J. T. (ed.) Quaternary environments eastern Canadian Arctic, Baffin Bay and western Greenland. 461-501. Boston: Allen and Unwin.

Kelly, M. \& Bennike, O. 1992: Quaternary geology of western and central North Greenland. Geological Survey of Greenland, report 153, 34 pp.

Kelly, M. and Landvik, J. 1990: Summary of regional glaciation history. In: Funder, S. (ed.) Late Quaternary stratigraphy and glaciology in the Thule area, Northwest
Greenland. Meddelelser om Grønland, Geoscience 22, 63 pp.

Landvik, J. Y. 1994: The last glaciation of Germania Land and adjacent areas, northeast Greenland. Joumal of Quaternary Science 9, 81-92.

Letréguilly, A., Huybrechts, P. \& Reeh, N. 1991: Steadystate characteristics of the Greenland ice sheet under different climates. Journal of Glaciology 37, 149-157.

Lyså, A. \& Landvik, J. 1994: The lower Jyllandselv succession: evidence for three Weichselian glacier advances over coastal Jameson Land, East Greenland. Boreas 23, 432447.

Marienfeld, P. 1991: Holozäne Sedimentationsentwicklung im Scoresby Sund, Ost-Grönland. Berichte zur Polarforschung 96, $162 \mathrm{pp}$.

Marienfeld, P. 1992: Postglacial sedimentary history of Scoresby Sund, East Greenland. Polarforschung 60, 181195.

Mienert, J., Andrews, J. T. \& Milliman, J. D. 1992: The East Greenland continentalmargin $\left(65^{\circ} \mathrm{N}\right)$ since the last deglaciation: changes in seafloor properties and ocean circulation. Marine Geology 106, 217-238.

Mörner, N.-A. \& Funder, S. 1990 : C-14 dating of samples collected during the NORDQUA 86 expedition, and notes on the marine reservoir effect. In Funder, S. (ed.) Late Quaternary stratigraphy and glaciology in the Thule area, Northwest Greenland. Meddelelser om Grønland, Geoscience 22, 57-59.

Nam, S.-I., Stein, R., Grobe, H. \& Hubberten, H. 1995: Late Quaternary glacial/interglacial changes in sediment composition at the East Greenland continental margin and their paleoceanographic implications. Marine Geology 122, 243-262.

Nichols, R. L. 1969: Geomorphology of Inglefield Land, North Greenland. Meddelelser om Grønland 188, 1, 109 pp.

Olesen, O. B., Weidick, A., Reeh, N., Thomsen, H. H., Braithwaite, R. J. \& Bøggild, C. E. 1995: Environmental impact on Greenland glaciers. Grønlands Geologiske Unders $\emptyset$ gelse, Rapport 165, 79-87.

Ohmura, A. \& Reeh, N. 1991: New precipitation and accumulation maps for Greenland. Journal of Glaciology 37, 140-148.

Peltier, R. W. 1994: Ice age paleotopography. Science 265, 195-201.

Roksandic, M. M. 1979: Geology of the continental shelf off West Greenland between $61^{\circ} 15^{\prime} \mathrm{N}$ and $64^{\circ} 00^{\prime} \mathrm{N}$. Grønlands geologiske Unders $\emptyset$ gelse, report $92,15 \mathrm{pp}$.

Sommerhoff, G. 1973: Formenschatz und Morphologische Gliederung des südostgrönländischen Schelfgebietes und Kontinentalabhanges. "Meteor" Forschungs-Ergebnisse C15, 54 pp.

Sommerhoff, G. 1975: Versuch einer geomorphologischen Gliederung des südwestgrönländischen Kontinentalabhanges. Polarforschung 45, 87-101.

Stein, R., Nam, S.-I., Schubert, C., Vogt, C., Fütterer, D. \& Heinemeier, J. 1994: The last deglaciation event in the eastern central Arctic Ocean. Science 264, 692-696.

Stein, R., Nam, S.-I., Grobe, H. \& Hubberten, H. in press: Late Quaternary glacial history and short term IRD fluctuations along the east Greenland continental margin. Special Publications of the Geological Society, London.

Svendsen, J. I. \& Mangerud 1987: Late Weichselian and Holocene sea-level history for a cross-section of western Norway. Journal of Quaternary Science 2, 113-132. 
Tauber, H. \& Funder, S. $1975 .{ }^{14} \mathrm{C}$ content of recent molluscs from Scoresby Sund, central East Greenland. Grønlands geologiske Unders $\varnothing$ gelse, report 75, 95-99.

Ten Brink, N. W. \& Weidick, A. 1974: Greenland ice sheet history since the last glaciation. Quaternary Research 4, 429-440.

Tveranger, J., Houmark-Nielsen, M., Løvberg, K. \& Mangerud, J. 1994: Eemian-Weichselian stratigraphy of the Flakkerhuk ridge, southern Jameson Land, East Greenland. Boreas 23, 359-385.

Weidick, A. 1975: Quaternary geology of the area between Frederikshåbs Isblink and Ameralik. Grønlands geologiske Undersøgelse, report 70, $22 \mathrm{pp}$.

Weidick, A. 1976: Glaciation and the Quaternary. In Escher, A. \& Watt, W. S. (eds) Geology of Greenland. 431-458. Copenhagen: The Geological Survey of Greenland.

Weidick, A. 1984: Studies of glacier behaviour and glacier mass balance in Greenland - a review. Geografiska annaler 66A, 181-195.

Weidick, A. 1993: Neoglacial change of ice cover and the related response of the Earth's crust in West Greenland. Grønlands geologiske Unders $\varnothing$ gelse, report 159, 121-126.

Williams, K. 1993: Ice sheet and ocean interactions, margin of the East Greenland ice sheet (14 ka to present): diatom evidence. Paleoceanography 8, 69-83. 